\title{
Effects of a new intravenous electrolyte solution for veterinary therapy on the electrolyte and acid-base balances of healthy horses
}

\author{
Efeito de uma nova solução eletrolítica intravenosa para uso veterinário \\ sobre os equilíbrios eletrolítico e ácido base de equinos sadios
}

\author{
Priscilla Fajardo Valente Pereira ${ }^{\mathrm{I}}$ José Antonio Bessegatto ${ }^{\mathrm{II}}$ Gabriela de Castro Bregadioli ${ }^{\mathrm{II}}$ \\ Stéfany Lia Oliveira Camilo ${ }^{\text {III }}$ Nathali Adrielli Agassi de Sales ${ }^{\text {II }}$ \\ Karina Keller Marques da Costa Flaiban ${ }^{\mathrm{IV}}$ Júlio Augusto Naylor Lisbôa $^{\mathrm{I}^{*}}$
}

\section{ABSTRACT}

The effects of a new intravenous electrolyte solution for veterinary therapy on electrolyte and acid-base balances of horses were evaluated, assessing the potential of the use of this solution as a rational alternative in fluid therapy. Eight healthy adult horses, including 4 males and 4 females, received two treatments in a cross-over design: isotonic saline solution (IS) and a test solution (TS) containing $145 \mathrm{mEq}$ of $\mathrm{Na}^{+}, 5 \mathrm{mEq}$ of $\mathrm{K}^{+}, 4 \mathrm{mEq}$ of $\mathrm{Ca}^{++}, 2 \mathrm{mEq}$ of $\mathrm{Mg}^{++}, 96 \mathrm{mEq}$ of $\mathrm{Cl}, 60 \mathrm{mEq}$ of lactate, $50 \mathrm{~g}$ of dextrose, and $4 \mathrm{mg}$ of cyanocobalamin per liter. Solutions were IV infused in a volume corresponding to $5 \%$ of $B W$, over 3 hours. Venous blood samples were taken 5 times before and after the infusion (at 0, 3, 6, 9 e 24h), for $\mathrm{pHv}, \mathrm{pCO}_{2} v, \mathrm{HCO}_{3}^{-} v, \mathrm{BEv}, \mathrm{Na}^{+}, \mathrm{K}^{+}, \mathrm{Cl}, \mathrm{Ca}^{++}, \mathrm{Ca}, \mathrm{P}, \mathrm{Mg}$, glucose and L-lactate measurements, and $A G$ and SID calculations. The data were analyzed through repeated measures ANOVA. The IS caused mild acidifying effect by increasing $\mathrm{Cl}$ and decreasing plasma SID. In contrast, the TS induced mild and transient hypochloremia without changes in acid-base balance. Hyperglycemia was present at the end of the TS infusion and reversed 6 hours later. The horses did not exhibit any clinical changes. We concluded that TS is an option for fluid therapy in horses.

Key words: fluid therapy, electrolyte, strong ion difference, rehydration.

\section{RESUMO}

Considerando a possibilidade de ser empregada como alternativa racional na terapia com fluidos, avaliaram-se os efeitos de uma nova solução eletrolítica intravenosa, desenvolvida para uso veterinário, sobre os equilibrios eletrolítico e ácido base de equinos. Oito equinos adultos sadios, quatro machos e quatro fêmeas, foram submetidos a dois tratamentos em delineamento cross-over: solução salina isotônica (SI) e solução teste (ST), composta por $145 \mathrm{mEq}$ de $\mathrm{Na}^{+}, 5 \mathrm{mEq}$ de $\mathrm{K}^{+}, 4 \mathrm{mEq}$ de $\mathrm{Ca}^{++}, 2 \mathrm{mEq}$ de $\mathrm{Mg}^{++}$, $96 \mathrm{mEq}$ de $\mathrm{Cl}$, $60 \mathrm{mEq}$ de lactato, $50 \mathrm{~g}$ de dextrose e $4 \mathrm{mg}$ de cianocobalamina por litro. As soluções foram administradas por via intravenosa, em volume correspondente a $5 \%$ do peso corporal, durante três horas de infusão contínua. Amostras de sangue venoso foram colhidas em cinco momentos, antes e após a infusão (0, 3, 6, 9 e 24h), para determinações de $\mathrm{pHv}, \mathrm{pCO}_{2}$, $\mathrm{HCO}_{3}^{-} v, \mathrm{BEv}, \mathrm{Na}^{+}, \mathrm{K}^{+}, \mathrm{Cl}, \mathrm{Ca}{ }^{++}, \mathrm{Ca}, \mathrm{P}, \mathrm{Mg}$, glicose e lactato $\mathrm{L}$, e para cálculo de $A G$ e SID. Os resultados foram analisados por análise de variância de medidas repetidas. Enquanto a SI gerou efeito acidificante discreto, com elevação da cloremia e redução da SID plasmática, a ST causou hipocloremia discreta e transitória e não interferiu com o equilibrio ácido base. A hiperglicemia, presente ao final da infusão da $S T$, reverteu-se seis horas após. Os equinos não manifestaram alterações clínicas. Conclui-se que a ST é uma alternativa para a terapia com fluidos em equinos.

Palavras-chave: terapia com fluidos, eletrólitos, diferença de ions fortes, hidratação.

\section{INTRODUCTION}

Fluid therapy is a routine procedure in the intensive care of horses. Fluid, electrolyte

\footnotetext{
IDepartamento de Clínicas Veterinárias (DCV), Centro de Ciências Agrárias (CCA), Universidade Estadual de Londrina (UEL), Campus Universitário, Rodovia Celso Garcia Cid, PR 445, Km 380, 86057-970, Londrina, PR, Brasil. E-mail: janlisboa@uel.br. ${ }^{*}$ Corresponding author.

IIPrograma de Pós-graduação em Ciência Animal, Centro de Ciências Agrárias (CCA), Universidade Estadual de Londrina (UEL), Londrina, PR, Brasil.

IIIDepartamento de Medicina Veterinária, Centro de Ciências Agrárias (CCA), Universidade Estadual de Londrina (UEL), Londrina, PR, Brasil.

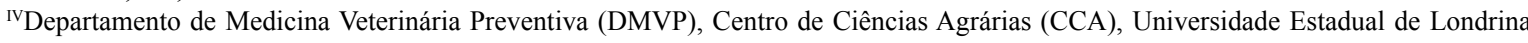
(UEL), Londrina, PR, Brasil. 
and acid-base imbalances can be severe in some horse diseases, particularly those that affect the digestive tract and cause colic (DI FILIPPO et al., 2008). The rapid correction of these imbalances can only be achieved via intravenous administration of electrolyte solutions (MAGDESIAN, 2015). Crystalloid solutions that carry electrolyte concentrations that are relatively balanced with those of the plasma and exhibit osmolarities that are similar to that of the plasma are denominated as iso-osmotic or isotonic and are appropriate for large volume infusions (RADOSTITS et al., 2007).

The isotonic saline solution $(\mathrm{NaCl} 0.9 \%)$, Ringer's solution, and Lactated Ringer's solution (LRS) are produced in Brazil for human use, have iso-osmotic properties, and are, also, employed in the treatment of horses. In the brazilian veterinary market, few solutions are available for use in horses. These solutions typically do not have balanced electrolyte concentrations and contain elevated concentration of glucose, which makes them hyperosmotic and unsuitable for administration in large volumes.

Evidence in humans has accumulated in support to the concept that hyperchloremia should be avoided because it is related to other indicators of poor prognoses and is associated with a high mortality rate (BONIATTI et al., 2011). Sick individuals tend to retain chloride $\left(\mathrm{Cl}^{-}\right)$in the body due to reduction in the renal excretion of this ion (MASEVICIUS et al., 2013), and the infusion of electrolyte solutions containing elevated $\mathrm{Cl}^{-}$concentrations may be unsuitable and contribute to the worsening of this imbalance (YOUNG et al., 2014). Although scientific verification is needed, it has been suggested that the same principles can be applied to equine species (FIELDING, 2014). In this context, LRS is the unique commercial option, available in Brazil, that contains reduced $\mathrm{Cl}^{-}$concentration and sodium-to-chloride ratio $\left(\mathrm{Na}^{+}: \mathrm{Cl}^{-}\right)$that is similar to that of the plasma. Due to these features, LRS should be considered as unique among the polyionic solutions as truly balanced and safe for prolonged administration in large volumes, because it does not cause iatrogenic electrolyte or acid-base imbalances (COSENZA et al., 2013).

A new electrolyte solution was developed for veterinary use. This solution is composed of electrolyte concentrations that are relatively similar to those of the plasma in physiological conditions, and contains reduced $\mathrm{Cl}$ - concentration and a high $\mathrm{Na}^{+}: \mathrm{Cl}^{-}$ratio. Due to its composition, this solution is probably an alternative to LRS for fluid therapy in horses, but its safety requires testing. The aims of this research were to evaluate the effects of this new electrolyte solution on the electrolyte and acidbase balances of healthy horses and to identify the possible adverse effects.

\section{MATERIALS AND METHODS}

The tested solution (TS) had the following composition: $145 \mathrm{mEq} \mathrm{L}-1$ of sodium $\left(\mathrm{Na}^{+}\right), 5 \mathrm{mEq} \mathrm{L} \mathrm{L}^{-1}$ of potassium $\left(\mathrm{K}^{+}\right), 4 \mathrm{mEq} \mathrm{L}{ }^{-1}$ of calcium $\left(\mathrm{Ca}^{++}\right), 2 \mathrm{mEq}$ $\mathrm{L}^{-1}$ of magnesium $\left(\mathrm{Mg}^{++}\right), 96 \mathrm{mEq} \mathrm{L}^{-1}$ of chloride $\left(\mathrm{Cl}^{-}\right), 60 \mathrm{mEq} \mathrm{L}^{-1}$ of lactate, and $50 \mathrm{~g} \mathrm{~L}^{-1}$ of dextrose. An ampoule containing $2 \mathrm{mg}$ of cyanocobalamin was added to each $500 \mathrm{~mL}$ bottle of the solution at the time of infusion. The calculated osmolarity was $562 \mathrm{mOsm}$ $\mathrm{L}^{-1}$, which is similar to the osmolarity of $5 \%$ dextrose in $0.9 \% \mathrm{NaCl}$ commercial solution.

Eight healthy adult horses $(10.3 \pm 2.1$ years), including four males and four females, weighing $389.3 \pm 53.2 \mathrm{~kg}$, were used in the current study. The females were not pregnant or lactating. The animals received ivermectin and praziquantel ${ }^{\mathrm{a}}$, and were kept in Coast-cross (Cynodon dactylon) grass paddocks. They were fed with the same grass hay as complement, and had free access to water and mineral supplement.

Each horse was subjected to two treatments in a randomized cross-over design. The order of the treatments was determined by drawing and the interval between treatments was five days. In the control treatment, the animals received commercial isotonic saline (IS) solution $(\mathrm{NaCl}$ $0.9 \%)^{\mathrm{b}}$. In the test treatment, the animals received the TS described above. A $14 \mathrm{G}$ IV catheter $^{\mathrm{c}}$ was fixed in the jugular vein and the solutions were infused at a rate of $17 \mathrm{~mL} \mathrm{~kg}^{-1} \mathrm{~h}^{-1}$, over 3 hours of continuous administration for a total volume that corresponded to $5 \%$ of body weight (BW).

Physical examinations, including rectal temperature and heart and respiratory rates measurements, were performed every hour during the intravenous infusions and preceding the defined blood sample collection time points. After the beginning of each treatment, the horses were continuously monitored for 24 hours to evaluate their behaviors, appetites and attitudes.

Venous blood samples were collected at the following five specific time points: immediately prior to the start of the infusion (0h), at the end of the infusion (3h), and at $6 \mathrm{~h}, 9 \mathrm{~h}$, and $24 \mathrm{~h}$. The blood samples were collected by jugular puncture with the vacuum collection system $21 \mathrm{G}$ needle $(25 \mathrm{x} 0.8 \mathrm{~mm})$, and vials containing sodium fluoride, for plasma glucose and L-lactate measurements; and vials with no 
anticoagulant, for total calcium $(\mathrm{Ca})$, phosphorus $(\mathrm{P})$, and magnesium $(\mathrm{Mg})$ determinations. The plasma was obtained by centrifugation that was performed at most ten minutes after sample collection, and the analyses were performed within 8 hours. The blood sera were obtained by centrifugation after clot retraction and were preserved by freezing $\left(-20^{\circ} \mathrm{C}\right)$ until analyses. Venous blood samples intended for blood gas analyses were collected from the jugular with $3 \mathrm{~mL}$ plastic syringes, coupled to $21 \mathrm{G}$ hypodermic needles (30x0.08mm) containing approximately $0.08 \mathrm{~mL}$ of sodium heparin as anticoagulant. The analyses were performed immediately after collection.

The plasma concentrations of L-lactate and glucose and the serum concentrations of $\mathrm{Ca}, \mathrm{P}$, and $\mathrm{Mg}$ were determined with colorimetric methods ${ }^{\mathrm{d}}$. Blood $\mathrm{pHv}, \mathrm{pCO}_{2} \mathrm{v}, \mathrm{HCO}_{3}^{-} \mathrm{v}$, base excess (BEv), $\mathrm{Na}^{+}$, $\mathrm{K}^{+}, \mathrm{Cl}^{-}$, and ionized calcium $\left(\mathrm{Ca}^{++}\right)$were determined with a blood gas analyser ${ }^{\mathrm{e}}$.

The following variables were calculated according to the respective formulas:

Anion Gap: $\mathrm{AG}=\left(\mathrm{Na}^{+}+\mathrm{K}^{+}\right)-\left(\mathrm{Cl}^{-}+\mathrm{HCO}_{3}^{-}\right)$.

Strong Ion Difference: $\mathrm{SID}=\left(\mathrm{Na}^{+}+\mathrm{K}^{+}\right)-\left(\mathrm{Cl}^{-}\right)$.

Two-way repeated measures analysis of variance was initially used to test the effects of time factor (before and after the administration of the solution), sex factor (males $x$ females), and the interaction between these two factors. Subsequently, two-way repeated measures analysis of variance was used to test the effects of time factor (before and after the administration of the solution), treatment factor (IS $\mathrm{x}$ TS) and the interaction between these two factors. Tukey's test was used for multiple comparisons, and the P-value was 0.05 . The SigmaStat 3.1 package for Windows was used to perform these tests.

\section{RESULTS AND DISCUSSION}

The studied variables were not influenced by the sexes of the animals $(\mathrm{P}>0.05)$, and the data analyses were performed ignoring this factor. The interactions between the factors time and treatment were proven $(\mathrm{P}<0.05)$ for all of the variables with the exception of $\mathrm{K}^{+}, \mathrm{AG}, \mathrm{Ca}, \mathrm{Ca}^{++}, \mathrm{Mg}$, and $\mathrm{P}(\mathrm{P}>0.05)$. The $\mathrm{pHv}, \mathrm{pCO}_{2} \mathrm{v}, \mathrm{HCO}_{3}^{-} \mathrm{v}, \mathrm{BEv}, \mathrm{Na}^{+}, \mathrm{K}^{+}, \mathrm{Cl}^{-}, \mathrm{SID}$, glucose, $\mathrm{L}$ lactate, and $\mathrm{Ca}$ values varied over time with or without the differences between the solutions. No effects $(\mathrm{P}>0.05)$ of the time after the infusion or the type of electrolyte solution employed were observed for AG or for the concentrations of $\mathrm{Ca}^{++}$, $\mathrm{Mg}$, and $\mathrm{P}$ (Table 1).

The TS did not cause changes in the acid-base balance when administered in a volume corresponding to $5 \%$ of $\mathrm{BW}$. The $\mathrm{pHv}$ values varied slightly $(\mathrm{P}<0.05)$, and the $\mathrm{pCO}_{2} \mathrm{v}, \mathrm{HCO}_{3}^{-} \mathrm{v}$, and $\mathrm{BEv}$ values did not change with the infusion $(\mathrm{P}>0.05$; Table 1); these values remained in the reference ranges for the species (RADOSTITS et al., 2007; CARLSON \& BRUSS, 2008). In contrast to the $\mathrm{TS}$, the isotonic $\mathrm{NaCl}$ solution (IS) caused a slight acidifying effect at the end of the infusion. The reductions in the $\mathrm{pHv}$ and $\mathrm{BEv}$ values $(\mathrm{P}<0.05$; Table 1) characterized the condition, and although acidemia was not present, the average BEv value was slightly below the lower physiological limit of $0 \mathrm{mmol}$ $\mathrm{L}^{-1}$ (RADOSTITS et al., 2007). This imbalance was low in magnitude and transient, but the BEv remained low three hours after the end of the IS administration.

The $\mathrm{pHv}, \mathrm{pCO}_{2} \mathrm{v}, \mathrm{HCO}_{3}^{-} \mathrm{v}$, and $\mathrm{BEv}$ values observed at the end of the infusion were always lower when horses received the IS $(\mathrm{P}<0.05)$, which characterized the distinct effects of both solutions on the acid-base balance. With the exception of the $\mathrm{pCO}_{2} \mathrm{v}$ value, these differences were prolonged for up to six hours after the end of the infusion (Table 1). Compensatory hypocapnia is the expected physiological response to situations of metabolic acidosis, and this response serves to correct acidemia and maintain the blood $\mathrm{pH}$ within physiological limits (CARLSON \& BRUSS, 2008). In the studied horses, hypocapnia was not observed, likely because these animals developed mild acidosis after receipt the IS. The mean $\mathrm{pCO}_{2} \mathrm{v}$ values did not differ over time, but the variability was greater at the end of the IS infusion, which reflected this physiological response.

Regarding the electrolyte balance, the two solutions triggered opposite imbalances, especially in terms to $\mathrm{Cl}^{-}$concentrations and plasma SID. The administration of the IS caused relative hyperchloremia at the end of the infusion $(\mathrm{P}<0.01)$ and did not interfere with the $\mathrm{Na}^{+}$concentration $(\mathrm{P}>0.05)$. This change affected the plasma SID, which was reduced at the end of the infusion $(\mathrm{P}<0.05$, Table 1). In contrast, the TS reduced the concentration of $\mathrm{Cl}^{-}(\mathrm{P}<0.01)$, which caused hypochloremia at the end of the infusion and also reduced the $\mathrm{Na}^{+}$concentration $(\mathrm{P}<0.05)$ but did not cause hyponatremia. Because there were decreases in both ions, the plasma SID in this case did not suffer interference and did not change over time $(\mathrm{P}>0.05)$. Similar to the $\mathrm{Na}^{+}$concentration, the $\mathrm{K}^{+}$ concentration remained within the physiological range of the species (CARLSON \& BRUSS, 2008), and the effects of the two solutions on this electrolyte did not differ $(\mathrm{P}>0.05)$; both were characterized by slight decreases at the end of the infusions $(\mathrm{P}<0.05)$. 
Table 1 - Mean ( \pm s.d.) values variations of the studied variables observed in healthy horses that received a tested electrolyte solution (TS) or the isotonic saline solution (IS) intravenously infused in a volume corresponding to $5 \%$ of BW, over three hours (from 0 to 3 hours).

\begin{tabular}{|c|c|c|c|c|c|}
\hline & 0 hour & 3 hours & 6 hours & 9 hours & 24 hours \\
\hline \\
\hline IS & $7.42^{\mathrm{Aa}} \pm 0.01$ & $7.39^{\mathrm{Bb}} \pm 0.02$ & $7.40^{\mathrm{Bab}} \pm 0.01$ & $7.41^{\mathrm{Bab}} \pm 0.01$ & $7.40^{\mathrm{Aab}} \pm 0.01$ \\
\hline TS & $7.43^{\mathrm{Aab}} \pm 0.02$ & $7.42^{\mathrm{Ab}} \pm 0.01$ & $7.44^{\mathrm{Aab}} \pm 0.02$ & $7.45^{\mathrm{Aa}} \pm 0.02$ & $7.41^{\mathrm{Ab}} \pm 0.01$ \\
\hline \multirow{3}{*}{$\begin{array}{l}\text { IS } \\
\text { TS }\end{array}$} & $41.90^{\mathrm{Aab}} \pm 3.80$ & \multirow{2}{*}{$\begin{array}{l}40.63^{\mathrm{Bb}} \pm 13.89 \\
44.90^{\mathrm{Aa}} \pm 4.74\end{array}$} & $\begin{array}{l}(\mathrm{mmHg}) \\
40.72^{\mathrm{Aab}} \pm 4.09\end{array}$ & $41.81^{\mathrm{Aab}} \pm 3.57$ & $44.38^{\mathrm{Aa}} \pm 4.97$ \\
\hline & $44.76^{\mathrm{Aa}} \pm 5.44$ & & $42.76^{\mathrm{Aa}} \pm 4.85$ & $41.90^{\mathrm{Aa}_{ \pm}}{ }_{5.31}$ & $43.73^{\mathrm{Aa}} \pm 5.75$ \\
\hline & & \multirow{4}{*}{$\begin{array}{l}24.63^{\mathrm{Bb}} \pm 2.77 \\
28.67^{\mathrm{Aa}} \pm 2.83\end{array}$} & $\left(\mathrm{mmol} \mathrm{L}^{-1}\right)-----$ & - & \\
\hline \multirow{3}{*}{$\begin{array}{l}\text { IS } \\
\text { TS }\end{array}$} & $26.73^{\mathrm{Bab}} \pm 2.31$ & & $24.58^{\mathrm{Bb}} \pm 2.73$ & $25.87^{\mathrm{Bab}} \pm 1.93$ & $27.35^{\mathrm{Aa}} \pm 2.62$ \\
\hline & $29.48^{\mathrm{Aa}} \pm 4.97$ & & $28.30^{\mathrm{Aa}_{ \pm}} .17$ & $29.25^{\mathrm{Aa}} \pm 2.47$ & $28.36^{\mathrm{Aa}} \pm 2.32$ \\
\hline & & & amol L $\left.\mathrm{L}^{-1}\right)$-------- & & \\
\hline \multirow{2}{*}{$\begin{array}{l}\text { IS } \\
\text { TS }\end{array}$} & $2.41^{\mathrm{Ba}} \pm 2.14$ & \multirow{2}{*}{$\begin{array}{l}-0.22^{\mathrm{Bb}} \pm 2.99 \\
4.60^{\mathrm{Aa}} \pm 3.32\end{array}$} & $0.43^{\mathrm{Bb}} \pm 2.29$ & $1.33^{\mathrm{Bab}} \pm 1.77$ & $2.77^{\mathrm{Aa}} \pm 2.55$ \\
\hline & $4.52^{\mathrm{Aa}} \pm 4.45$ & & $4.22^{\mathrm{Aa}} \pm 1.83$ & $4.85^{\mathrm{Aa}} \pm 2.54$ & $3.07^{\mathrm{Aa}} \pm 3.13$ \\
\hline \multirow{4}{*}{$\begin{array}{l}---- \\
\text { IS } \\
\text { TS }\end{array}$} & & \multirow{3}{*}{$\begin{array}{l}139.45^{\mathrm{Aa}} \pm 5.75 \\
134.08^{\mathrm{Bb}} \pm 3.73\end{array}$} & amol L L & & \\
\hline & $137.63^{\mathrm{Aa}} \pm 6.33$ & & $139.62^{\mathrm{Aa}} \pm 6.87$ & $139.06^{\mathrm{Aa}} \pm 7.59$ & $138.42^{\mathrm{Aa}} \pm 5.21$ \\
\hline & $138.66^{\mathrm{Aa}} \pm 2.35$ & & $139.01^{\mathrm{Aa}} \pm 5.27$ & $138.10^{\mathrm{Aa}} \pm 5.25$ & $138.95^{\mathrm{Aa}} \pm 4.54$ \\
\hline & & \multirow{4}{*}{$\begin{array}{l}3.29^{\mathrm{Ab}} \pm 0.35 \\
3.07^{\mathrm{Ab}} \pm 0.21\end{array}$} & mol L-1)-------- & & \\
\hline \multirow{3}{*}{ IS } & $3.90^{\mathrm{Aa}} \pm 0.20$ & & $3.54^{\mathrm{Aab}} \pm 0.47$ & $3.67^{\mathrm{Aab}} \pm 0.37$ & $3.87^{\mathrm{Aa}} \pm 0.32$ \\
\hline & $3.81^{\mathrm{Aa}} \pm 0.38$ & & $3.19^{\mathrm{Aab}} \pm 0.38$ & $3.41^{\mathrm{Aab}} \pm 0.39$ & $3.60^{\mathrm{Aa}} \pm 0.29$ \\
\hline & & & mol L L & & \\
\hline \multirow{3}{*}{$\begin{array}{l}\text { IS } \\
\text { TS }\end{array}$} & $101.08^{\mathrm{Ab}} \pm 6.10$ & \multirow{3}{*}{$\begin{array}{l}106.31^{\mathrm{Aa}} \pm 4.19 \\
95.96^{\mathrm{Bb}} \pm 3.58\end{array}$} & $104.30^{\mathrm{Aab}} \pm 6.26$ & $102.80^{\mathrm{Aab}} \pm 6.61$ & $101.21^{\mathrm{Ab}} \pm 5.18$ \\
\hline & $101.02^{\mathrm{Aa}} \pm 4.56$ & & $101.93^{\mathrm{Aa}} \pm 4.81$ & $102.80^{\mathrm{Aa}} \pm 5.28$ & $101.81^{\mathrm{Aa}} \pm 6.28$ \\
\hline & & & $\left.\mathrm{mol} \mathrm{L} \mathrm{L}^{-1}\right)$ & & \\
\hline \multirow{2}{*}{$\begin{array}{l}\text { IS } \\
\text { TS }\end{array}$} & $40.45^{\mathrm{Aa}} \pm 1.28$ & \multirow{2}{*}{$\begin{array}{l}36.43^{\mathrm{Bb}} \pm 3.42 \\
41.20^{\mathrm{Aa}} \pm 3.41\end{array}$} & $38.87^{\mathrm{Aab}} \pm 2.45$ & $39.93^{\mathrm{Aab}} \pm 3.23$ & $41.09^{\mathrm{Aa}} \pm 1.15$ \\
\hline & $41.44^{\mathrm{Aa}} \pm 3.49$ & & $40.27^{\mathrm{Aa}} \pm 2.78$ & $38.71^{\mathrm{Aa}} \pm 3.95$ & $40.73^{\mathrm{Aa}} \pm 2.64$ \\
\hline ---- & 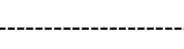 & \multirow{3}{*}{$\begin{array}{l}11.79 \pm 4.76 \\
12.52 \pm 2.99\end{array}$} & nol L $\left.{ }^{-1}\right)$---------. & & \\
\hline \multirow{2}{*}{$\begin{array}{l}\text { IS } \\
\text { TS }\end{array}$} & $13.71 \pm 2.49$ & & $14.28 \pm 3.40$ & $14.06 \pm 3.84$ & $13.74 \pm 2.38$ \\
\hline & $11.96 \pm 3.67$ & & $11.97 \pm 3.77$ & $10.00 \pm 5.57$ & $12.37 \pm 2.52$ \\
\hline \multirow{2}{*}{$\begin{array}{l}\text { IS } \\
\text { TS }\end{array}$} & $0.27^{\mathrm{Aa}} \pm 0.12$ & \multirow{2}{*}{$\begin{array}{l}0.22^{\mathrm{Ba}} \pm 0.08 \\
1.56^{\mathrm{Aa}} \pm 0.82\end{array}$} & $\begin{array}{c}\left(\mathrm{mmol} \mathrm{L}^{-1}\right) \text {------ } \\
0.22^{\mathrm{Ba}} \pm 0.10\end{array}$ & $0.38^{\mathrm{Aa}} \pm 0.17$ & $0.30^{\mathrm{Aa}} \pm 0.27$ \\
\hline & $0.36^{\mathrm{Ab}} \pm 0.23$ & & $0.62^{\mathrm{Ab}} \pm 0.34$ & $0.40^{\mathrm{Ab}} \pm 0.24$ & $0.43^{\mathrm{Ab}} \pm 0.23$ \\
\hline \multirow{3}{*}{$\begin{array}{l}--- \\
\text { IS }\end{array}$} & $78.75^{\mathrm{Aa}} \pm 6.96$ & \multirow{2}{*}{$\begin{array}{l}82.87^{\mathrm{Aa}} \pm 10.32 \\
462.37^{\mathrm{Ba}} \pm 69.13\end{array}$} & $\begin{array}{l}\left(\mathrm{mg} \mathrm{dL}^{-1}\right)---- \\
80.50^{\mathrm{Aa}} \pm 10.36\end{array}$ & $84.12^{\mathrm{Aa}} \pm 12.59$ & $77.12^{\mathrm{Aa}} \pm 8.93$ \\
\hline & $84.50^{\mathrm{Ab}_{ \pm}} \pm 10.92$ & & $136.75^{\mathrm{Ba}} \pm 49.25$ & $73.62^{\mathrm{Ab}} \pm 17.76$ & $81.12^{\mathrm{Ab}} \pm 7.18$ \\
\hline & & \multirow{3}{*}{$\begin{array}{l}11.00^{\mathrm{Ab}} \pm 0.69 \\
11.04^{\mathrm{Ab}} \pm 0.70\end{array}$} & $\operatorname{lm}\left(\mathrm{mg} \mathrm{dL}^{-1}\right)-$ & --------------------- & -------------------- \\
\hline \multirow{3}{*}{$\begin{array}{l}\text { IS } \\
\text { TS }\end{array}$} & $12.73^{\mathrm{Aa}} \pm 2.00$ & & $11.18^{\mathrm{Aab}} \pm 1.54$ & $11.78^{\mathrm{Aab}} \pm 0.69$ & $12.11^{\mathrm{Aa}} \pm 1.09$ \\
\hline & $11.54^{\mathrm{Aab}} \pm 0.29$ & & $11.77^{\mathrm{Aab}} \pm 1.12$ & $12.08^{\mathrm{Aab}} \pm 0.39$ & $12.23^{\mathrm{Aa}} \pm 0.59$ \\
\hline & & \multirow{3}{*}{$\begin{array}{l}5.21 \pm 0.77 \\
5.27 \pm 0.50\end{array}$} & ium $\left(\mathrm{mg} \mathrm{dL}^{-1}\right)-$ & & \\
\hline \multirow{2}{*}{$\begin{array}{l}\text { IS } \\
\text { TS }\end{array}$} & $5.03 \pm 0.77$ & & $5.44 \pm 0.83$ & $5.55 \pm 0.85$ & $5.51 \pm 0.74$ \\
\hline & $5.28 \pm 0.76$ & & $5.29 \pm 0.90$ & $5.08 \pm 0.61$ & $5.15 \pm 0.53$ \\
\hline & & 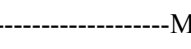 & $m\left(m g \mathrm{dL}^{-1}\right)---$ & & \\
\hline & $2.04 \pm 0.63$ & $1.72 \pm 0.19$ & $1.95 \pm 0.26$ & $2.09 \pm 0.28$ & $1.89 \pm 0.23$ \\
\hline TS & $1.62 \pm 0.19$ & $1.84 \pm 0.39$ & $2.07 \pm 0.46$ & $2.07 \pm 0.46$ & $1.92 \pm 0.36$ \\
\hline IS & $3.36 \pm 1.04$ & $2.88 \pm 0.88$ & $2.86 \pm 0.89$ & $2.75 \pm 0.71$ & $3.15 \pm 0.93$ \\
\hline TS & $3.06 \pm 0.61$ & $2.13 \pm 0.37$ & $2.67 \pm 1.06$ & $2.62 \pm 0.67$ & $3.20 \pm 0.79$ \\
\hline
\end{tabular}

${ }^{\mathrm{A}, \mathrm{B}}$ means difference between the IV solutions in each time point $(\mathrm{P}<0,05)$; ${ }^{\text {a b }}$ means difference between the moments in each IV solution $(\mathrm{P}<0,05)$.

The plasma SID of healthy horses is close to $40 \mathrm{mmol} \mathrm{L}^{-1}$ (CONSTABLE, 1997). This variable is calculated as the difference between the concentrations of strong cations $\left(\mathrm{Na}^{+}\right.$and $\left.\mathrm{K}^{+}\right)$and strong anions $(\mathrm{Cl})$ 
in the plasma, as defined by those ions that are always present in dissociated forms at physiological $\mathrm{pH}$ (CONSTABLE, 2000). The SID is therefore a measure of the relationship between the main plasma ions, notably $\mathrm{Na}^{+}$and $\mathrm{Cl}^{-}$, present with higher concentrations. The same concept can be applied to the electrolyte solutions. While the IS has an effective SID equal to $0 \mathrm{mEq} \mathrm{L} \mathrm{L}^{-1}$, due to the equivalent amounts of $\mathrm{Na}^{+}$and $\mathrm{Cl}^{-}\left(154 \mathrm{mEq} \mathrm{L}{ }^{-1}\right.$ each), the TS has an effective SID equal to $54 \mathrm{mEq} \mathrm{L}^{-1}$ because the concentration of $\mathrm{Cl}^{-}\left(96 \mathrm{mEq} \mathrm{L}^{-1}\right)$ is less than that of $\mathrm{Na}^{+}(145 \mathrm{mEq}$ $\left.\mathrm{L}^{-1}\right)$. Therefore, when administered rapidly and in large volumes, the $\mathrm{NaCl}$ isotonic solution causes hyperchloremia and consequently reduction in plasma SID (CONSTABLE, 2014), which explains the results observed in the studied horses. In contrast, the TS contains concentrations of $\mathrm{Na}^{+}$and $\mathrm{Cl}^{-}$that are more similar to those of the plasma and thus does not interfere with the plasma SID.

Based on the simplified strong ion approach applied to the interpretation of the acid-base balance, it can be said that the acidifying effect observed with the IS infusion resulted from the electrolyte imbalance caused by this solution (CONSTABLE, 2014). For example, in diarrheic calves, the blood $\mathrm{pH}$ value may be reduced by 0,013 units for each $1.0 \mathrm{mmol} \mathrm{L}^{-1}$ decrease in the plasma SID value (CONSTABLE et al., 2005). The same concept can be applied to equine plasma (CONSTABLE, 1997). Thus, because the isotonic $\mathrm{NaCl}$ solution causes hyperchloremia and acidification (hyperchloremic acidosis), this solution could be considered an appropriate electrolyte solution for infusion into animals with hypochloremic metabolic alkalosis.

Regarding the TS, the absence of interference with the acid-base balance is attributable to the absence of effect on the plasma SID, although this solution caused transient hypochloremia. In this regard, the TS exerted effects that were more similar to those of LRS, which does not cause electrolyte or acid-base imbalances even when administered in volumes corresponding to $10 \%$ of $\mathrm{BW}$ (COSENZA et al., 2013). Similar to LRS, which is considered a balanced electrolyte solution, the TS contains electrolyte concentrations that are relatively similar to those of the plasma, which explains the absence of iatrogenic imbalances. However, in contrast to LRS, which has an effective SID of $28 \mathrm{mEq} \mathrm{L}^{-1}$, the TS has a nearly two-fold greater effective SID value. Judging from the results that have been recently demonstrated in healthy calves, regarding the comparative effects of solutions containing different sodium lactate concentrations (JUNQUEIRA et al., 2015), this feature would most likely provide the TS with an alkalizing effect following administration in volumes greater than those used in the current study. Due to its properties and effects, the TS should most properly be indicated for infusion into horses suffering from hyperchloremic metabolic acidosis and those without electrolyte imbalances.

Notably and as previously mentioned, the iatrogenic electrolyte imbalances observed in the studied horses were mild and transient. The alterations in the $\mathrm{Cl}^{-}$and SID values that were observed at the end of the infusions did not differ from the baseline values after 3 hours (Table 1). The low magnitude of the imbalances is attributable to the fact that the infused volume was limited to only $5 \%$ of BW. The short duration of the imbalances was likely because healthy animals were used; therefore, the animals' kidneys were capable of promoting the efficient correction via selective ion excretion or retention.

Assuming that $1.5 \mathrm{mmol} \mathrm{L}^{-1}$ is the upper physiological limit of the L-lactate concentration in the equine plasma (TENNENT-BROWN, 2014), it can be stated that the TS infusion did not actually cause hyperlactatemia in the studied horses. The increased values observed at the end of the infusion (4.3-fold greater than the baseline values; $\mathrm{P}<0.001$ ) returned to the baseline concentration 3 hours later, although the differences between the two solutions were maintained until this moment (Table 1). Considering that the TS has $60 \mathrm{mEq} \mathrm{L}^{-1}$ of lactate, the horses received $3 \mathrm{mmol}$ of lactate per kilogram of BW; however, even at this dose, the horses did not develop hyperlactatemia. This finding can be explained by the very fast and efficient metabolism of the infused lactate in the healthy horses (DE PEDRO et al., 2012; TENNENT-BROWN, 2014).

In a pharmacokinetic study, DE PEDRO et al. (2012) intravenously infused $1 \mathrm{mmol} \mathrm{\textrm {kg } ^ { - 1 }}$ of L-lactate in healthy horses for 15 minutes and reported that most of the plasma clearance occurred within the following 20 minutes and reversed the hyperlactatemia present at the end of the infusion $\left(1.97 \pm 0.17 \mathrm{mmol} \mathrm{L}^{-1}\right)$. Comparatively, the horses in the current study received a three-fold greater amount of lactate per kilogram of BW, however this lactate was administered at a four-fold lower rate $\left(1 \mathrm{mmol} \mathrm{kg}^{-1} \mathrm{~h}^{-1}\right)$. It is correct to assume that lactate was continuously metabolized during the TS infusion, which thus avoided the installation of hyperlactatemia. Notably, the horses used in the current study were healthy and therefore had full hepatic metabolism capacities. It is likely that the metabolism of L-lactate is slower in horses suffering from liver disease, but the veracity of this hypothesis must be verified in future studies. 
The AG was maintained unchanged $(\mathrm{P}>0.05)$ in the horses throughout the study. This finding can be explained by the absence of changes in the plasma L-lactate concentration when the horses received the IS and by the slight and transient variation in the plasma L-lactate concentration when the horses received the TS. This hypothesis can be stated because to a large extend, the AG reflects the plasma concentrations of unmeasured anions, and L-lactate must be highlighted among this anions (CONSTABLE, 2000).

The glycemia did not change $(\mathrm{P}>0.05)$ with the infusion of the IS. In contrast, the dextrose $\left(50 \mathrm{~g} \mathrm{~L}^{-1}\right)$ provided by the TS caused hyperglycemia at the end of the infusion $(\mathrm{P}<0,001)$ that remained present for 3 hours and returned to physiological and baseline values 6 hours later (Table 1). The hyperglycemia in the studied horses was justified because they were normoglycemic animals that received an additional intravenous glucose load. The relatively rapid reversion of hyperglycemia is attributable to the fact that the healthy horses responded promptly with the release of insulin and that their cells responded properly to the stimulation with this hormone via the uptake of glucose into the intracellular space (GRAAF-ROELFSEMA, 2014). In practice, the infusion of intravenous solutions containing dextrose in anorexic and hypoglycemic sick animals could be advantageous due to reductions in the negative energy balance and protein catabolism (MAGDESIAN, 2015). The use of this solution for the treatment of animals with hyperglycemia is contraindicated. In normoglycemic animals, this type of solution must be carefully infused and may be considered safe since there is no insulin resistance (GRAAF-ROELFSEMA, 2014).

Regarding the concentrations of $\mathrm{Ca}^{++}, \mathrm{Mg}$, and $\mathrm{P}$, it can be assumed that both the TS and the IS failed to cause interference. The variation in the serum concentration of $\mathrm{Ca}$ was minimal $(\mathrm{P}<0.05$; Table 1$)$, and this finding has no biological significance. The concentrations of $\mathrm{Mg}$ and $\mathrm{P}$ were slightly below the lower physiological limits that are accepted for equine species (CARLSON \& BRUSS, 2008). The causes of these results remain unexplained, and these results are not related to the treatments performed.

Finally, it is notable that the infusion of the TS did not cause any apparent adverse effects in the studied animals. The horses remained healthy and exhibited good appetites and normal behaviors and attitudes during and after the infusions. The body temperature, heart and respiratory rates values remained unchanged and within the physiological ranges of variation that are accepted for this species. The same results were observed following the administration of the IS.

\section{CONCLUSION}

The electrolyte solution (TS) tested in the current study is presented as an option for fluid therapy in horses. The therapeutic efficacy of this solution should be proven in future studies.

\section{ACQUISITION SOURCE}

a - Handicap Equinos, Marcolab.

b - Fisiológico, Eurofarma.

c - BD Angiocath, Becton Dickinson Indústrias Cirúrgicas Ltda.

d - Dimension Clinical Chemistry System; Dade Behring; Siemens.

e - Omni C; Cobas B 121; Roche Diagnóstica do Brasil Ltda.

\section{BIOETHICS AND BIOSSECURITY COMMITTE APPROVAL}

The experimental protocol was approved by the Ethics Committee on Animal Use of the Universidade Estadual de Londrina (UEL), under the process number 2361.2013.16.

\section{ACKNOWLEDGEMENTS}

Júlio A.N. Lisbôa is recipient of the Conselho Nacional de Desenvolvimento Científico e Tecnológico (CNPq) fellowship.

\section{REFERENCES}

BONIATTI, M.M. et al. Is hyperchloremia associated with mortality in critically ill patients? A prospective cohort study. Journal of Critical Care, v.26, p.175-179, 2011. Available from: <http:// www.sciencedirect.com/science/article/pii/S0883944110001176>. Accessed: Aug. 15, 2015. doi: 10.1016/j.jcrc.2010.04.013.

CARLSON, G.P.; BRUSS, M.L. Fluid, eletrolyte, and acid-base balance. In: KANEKO, J.J. et al. Clinical biochemistry of domestic animals. 6.ed. Burlington: Elsevier, 2008. Cap.17, p.529-559.

CONSTABLE, P.D. A simplified strong ion model for acid-base equilibria: application to horse plasma. Journal of Applied Physiology, v.83, p.297-311, 1997. Available from: <http://jap. physiology.org/content/83/1/297>. Accessed: Feb. 24, 2015.

CONSTABLE, P.D. Clinical assessment of acid-base status: comparison of the Henderson-Hasselbalch and strong ion approaches. Veterinary Clinical Pathology, v.29, p.115-128, 2000. Available from: $<\mathrm{http}$ ://onlinelibrary.wiley.com/doi/10.1111/ j.1939-165X.2000.tb00241.x/full>. Accessed: Feb. 24, 2015. doi: 10.1111/j.1939-165X.2000.tb00241.x.

CONSTABLE, P.D. Acid-base assessment: when and how to apply the Henderson-Hasselbalch equation and strong ion difference theory. Veterinary Clinics of North America: Food Animal Practice, v.30, p.295-316, 2014. Available from: <http://dx.doi. org/10.1016/j.cvfa.2014.03.001>. Accessed: Jan. 30, 2015. doi: 10.1016/j.cvfa.2014.03.001. 
CONSTABLE, P.D. et al. Use of a quantitative strong ion approach to determine the mechanism for acid-base abnormalities in sick calves with or without diarrhea. Journal of Veterinary Internal Medicine, v.19, p.581-589, 2005. Available from $<$ http://onlinelibrary.wiley.com/doi/10.1111/j.1939-1676.2005. tb02731.x/epdf $>$. Accessed: Jan. 30, 2015. doi: 10.1111/j.19391676.2005.tb02731.x.

COSENZA, M. et al. Effect of lactated Ringer's solution on fluid, electrolyte and acid-base balances of healthy horses, ewes and calves. Ciência Rural, v.43, p.2247-2253, 2013. Available from: <http://dx.doi.org/10.1590/S010384782013005000128>. Accessed: Jan. 20, 2014. doi: 10.1590 S0103-84782013005000128.

DE PEDRO, P. et al. Exogenous L-lactate clearance in adult horses. Journal of Veterinary Emergency and Critical Care, v.22, p.564-572, 2012. Available from: $<$ http://onlinelibrary.wiley. $\mathrm{com} / \mathrm{doi} / 10.1111 / \mathrm{j} .1476-4431.2012 .00800 . \mathrm{x} / \mathrm{pdf}>$. Accessed: Jan. 30, 2015. doi: 10.1111/j.1476-4431.2012.00800.x.

DI FILIPPO, P.A. et al. Acid-base and hidroelectrolytic balance in colic horses. Ciência Rural, v.38, p.1003-1009, 2008. Available from: $<$ http://www.scielo.br/scielo.php?script $=$ sci arttext\&pid=S0103-84782008000400015\&lng=pt\&nrm=iso\&tln $\mathrm{g}=\mathrm{pt}>$. Accessed: Aug. 12, 2015.

FIELDING, L. Crystalloid and colloid therapy. Veterinary Clinics of North America: Equine Practice, v.30, p.415425, 2014. Available from: <http://dx.doi.org/10.1016/j. cveq.2014.04.008>. Accessed: Jan. 30, 2015. doi: 10.1016/j. cveq.2014.04.008.

GRAAF-ROELFSEMA, E. Glucose homeostasis and the enteroinsular axis in the horse: a possible role in equine metabolic syndrome. Veterinary Journal, v.199, p.11-18, 2014. Available from: <http://www.sciencedirect.com/science/
article/pii/S1090023313005066>. Accessed: Feb. 20, 2015. doi: $10.1016 /$ j.tvj1.2013.09.064.

JUNQUEIRA, J.R.C. et al. Alkalizing effect of intravenous electrolyte solutions with high sodium lactate concentrations infused in healthy calves. Arquivo Brasileiro de Medicina Veterinária e Zootecnia, v.67, p.15-24, 2015. Available from: $<$ http://dx.doi.org/10.1590/1678-6754>. Accessed: Mar. 23, 2015. doi: 10.1590/1678-6754.

MAGDESIAN, K.G. Critical care and fluid therapy. In: SMITH, B.P. Large animal internal medicine. 5.ed. Missouri: Elsevier, 2015. Cap.44, p.1369-1390.

MASEVICIUS, F.D. et al. Urinary strong ion difference is a major determinant of plasma chloride concentration changes in postoperative patients. Revista Brasileira de Terapia Intensiva, v.25, p.197-204, 2013. Available from: <http://www.rbti.org.br/ artigo/detalhes/0103507X-25-3-5>. Accessed: Aug. 12, 2015.

RADOSTITS, O.M. et al. Veterinary medicine - A textbook of the diseases of cattle, horses, sheep, pigs and goats. 10.ed. Philadelphia: Saunders Elsevier, 2007. 2156p.

TENNENT-BROWN, B. Blood lactate measurement and interpretation in critically ill equine adults and neonates. Veterinary Clinics of North America: Equine Practice, v.30, p.399-413, 2014. Available from: $<$ http://dx.doi.org/10.1016/j. cveq.2014.04.006>. Accessed: Jan. 30, 2015. doi: 10.1016/j. cveq. 2014.04 .006

YOUNG, J.B. et al. Saline versus Plasma-lyte A in initial resuscitationof trauma patients: a randomized trial. Annals of Surgery, v.259, p.255-262, 2014. Available from: <http:// journals.lww.com/annalsofsurgery/Abstract/2014/02000/Saline Versus_Plasma_Lyte_A_in_Initial.10.aspx>. Accessed: Aug. 12, 2015. doi: $10.1097 /$ SLA.0b013e318295feba. 